\title{
Analysis of the Use of Technological Tools in University Higher Education using the Soft Systems Methodology
}

\author{
Alexandra Ramos Bernaola ${ }^{1}$, Marianne Aldude Tipula ${ }^{2}$, Jose Estrada Moltalvo ${ }^{3}$ \\ Valeria Señas Sandoval ${ }^{4}$, Laberiano Andrade-Arenas ${ }^{5}$ \\ Facultad de Ciencias e Ingeniería \\ Universidad de Ciencias y Humanidades \\ Lima, Perú
}

\begin{abstract}
This article analyzes the professional training of students according to the current situation. Students are experiencing a new modality of study due to the Covid-19 and specialists have to evaluate which would be the best solutions in order that students achieve greater understanding, because they are one of the most affected today. Therefore, we will be able to analyze in a detailed way each one of the causes that our problem presents to evaluate and thus to be able to obtain the different points of view of those who are involved in this problem. In this study we will apply the methodology of the soft systems with a systemic approach and a holistic vision to analyze the situation presented by all those involved. Having as results that it is necessary to evaluate in a better way the solutions that are given to higher education institutions, since it should have as main objective the achievement of a better teaching towards the students and thus opting for the use of good methodologies of learning.
\end{abstract}

Keywords-Soft system; involved; university; virtual classroom; students

\section{INTRODUCTION}

This research reveals the work done based on the virtual classroom. The work consists of determining each of the procedures to be followed and controlling the regulations to be complied with through the implementation of a methodology that feeds the teachers. The complete study shows the results for the correct use of the platform that is the classroom virtual, helping both the university and all those involved. The updating of information and communication technologies in the educational field has allowed redesigning the scenarios where the teaching-learning processes takes place, which has caused the barrier between face-to-face, blended and virtual education to be increasingly shorter and equally between formal, non-formal and informal education; where the roles of teacher and student must change as stated by Salinas [1]. For instance, in Peru ICT are allowing to the population to access more easily internet [2]. In this way, a true revolution in the way of conceiving learning experiences is produced when compared to the way it was done before. It is important to indicate that a global level there is a massive identify of LMS (Learning Management Systems) platforms in practice [3]. The conditions of the new world, where knowledge is the most important heritage of humanity, make the educational models and, therefore, the institutions that have the social responsibility to form, radically renew their pedagogical practices and their ways of handling the learning. These aspects require the presence of teachers with more interdisciplinary training, with new and renewed methodological visions and with more capacity for the rational and adequate use of the available means, especially of the new information and communication technologies (ICT). Today's universities are recognized for their qualities: among others, for the quality of their teachers and, above all, for their ability to cope with the permanent changes demanded by the globalized world [4] in this perspective the use of (ICT ) as a didactic and pedagogical strategy in teaching practices takes on great importance [5]. The fundamental concept implicit in the latest online education experiences is the "VIRTUAL CLASSROOM", we wanted to do an analysis to propose and incorporate the use of Virtual Classrooms in Education as a technological support for teaching-learning that goes beyond what traditional classroom attendance represents [6]. Dr. Bello Díaz [7] calls virtual environments for learning "classrooms without walls" and affirms that it is a virtual social space, whose best current exponent is the internet, it is not face-toface, but representative, it is not proximal, but distal, it is not synchronous, but metachronous, and it is not based on spatial enclosures with interior, border and exterior, but rather depends on electronic networks whose interaction nodes may be scattered throughout different countries [8]. In recent years, technological innovations and social needs have become part of the difficulties of the environment, and these, together with those of the political sphere, are what make universities aware of the need to redefine their mission. Faced with this, Information and Communication Technologies (hereinafter ICT) not only allow universities to transform their administrative procedures, innovate their teaching-learning methodologies or facilitate access to new groups of people especially adults, but also promote a transformation in your organizational system. In this way, the ICTs affected by the structure of the university organization, its processes and its value chain [9] is why the use of the virtual platform will be implemented to speed up the teaching process. The objective of this article is to analyze the use of technological tools, as well as the strategy in virtual teaching, using the soft systems methodology. 


\section{MethodOLOGY}

In this study, the methodology of soft systems is used, in order to be able to analyze the technologies of university higher education. To achieve the study of this research, the mnemonic CATDWE is applied in the different stages to evaluate the perceptions of the different stakeholders. Later, in Section 3, we will explain the results by taking the studies and perspectives of those involved. [10]:

A brief explanation of the acronym CATDWE will follow

$\mathrm{C}$ : Client, which in these cases may be the provider, since they are the ones involved in the different problems to be analyzed.

A: Actor, who is in charge of executing the different actions that will be carried out to solve the problem being analyzed.

T: Transformation, at this point the current situation of the problem is analyzed in order to propose the future situation they hope to achieve.

D: Owner, are those who are responsible for the execution of the process that was analyzed, for its proper solution.

W: Weltannshaunng, are the different points of view that present the involved ones, which will be taken into account for the solutions.

E: Environment, are the different restrictions which limit the complete execution of the solutions, these restrictions must be identified and taken into account before making a solution plan.

\section{CASE STUDY}

\section{A. Unstructured Situation}

In this first stage the problem will be described as well as the causes found within this research work, therefore, we consider that the central problem is focused on the teaching process and on virtual learning in education provided at a higher level or in universities, taking into account different important points, which we highlight as the causes of this research. Therefore, as the first cause we have the virtual classroom, considered worldwide as a very efficient means by which fluid communication between the student and the teacher can be achieved, facilitating what has been learned in the different classes, either providing support with homework. or evaluations so that greater progress and understanding of the student is obtained. [11], managing to resemble a face-toface mode, since inquiries towards teachers take much longer to be answered, managing to not satisfy their concerns. [12]. As a second cause we have resources, which are the most important and necessary technological means for students, as well as for teachers, since the use of Information and Communication Technology (ICT) is considered a key factor, having So within the ICTs, we work with two essential technological resources such as virtual platforms (PV) and the virtual learning environment (EVA), since these two together provide tools which can be controlled by the tutor or the administrator [13], which can allow you to browse the Internet properly or allow you to correctly install the programs and applications that can facilitate your virtual studies [14]. Having, as a third cause to teaching, these within the environment of the teacher should have incorporated certain didactic materials so that knowledge can be expedited through different texts, images, videos or animations for the best understanding of the students [15]. For in Spain, the main objective is to encourage, tutor and be able to evaluate the different activities of intellectual participation that the students have [16], which therefore are proposed by the teacher to achieve great ease in the processing of information [17]. Thus we managed to have as a clear example of teaching strategies the use of forums, in which each student can express what was understood or learned in class, this was achieved by developing a large number of tools that have been implemented currently [18], taking as an example the research carried out at the University of León between the years 2009 to 2010, which shows the different dynamic perspectives such as integrating PPT in the virtual classroom, achieving a methodology, which tries to provide, information, training and help to give a series of information simultaneously to different participants according to their due disposition of technologies [19]. Other research that has focused on analyzing the type of practices developed by university professors through the platforms managed to reflect that the use of this methodology tends to reproduce educational models in a classical way, of which they are more oriented to transmission of information that to the participation of the students [20].

\section{B. Structured Situation}

In Fig. 1, you can see the stakeholders identified within the use of the Virtual Classroom are:

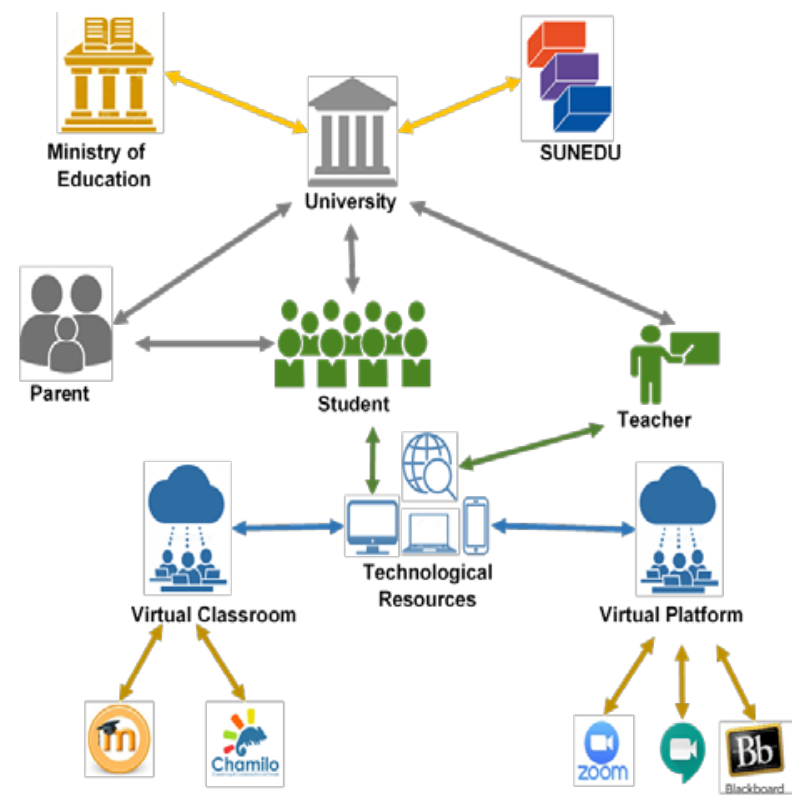

Fig. 1. Stakeholder Structure.

\section{Basic Definition}

- W1. STUDENT: The student is that subject whose main occupation is the activity of studying, perceiving it through the academic environment. Being the main function of the students to learn always new things about 
different subjects or branches of science and art, or any other area that can be put in study. Bearing in mind that the student carries out both the reading and the practice of the subject or theme on which he is learning [21].

\section{C: Student, Teacher, University}

\section{A: Ministry of Education, Sunedu}

T: In the transformation, two different visions can be observed, such as the current and future situation of the students, as seen in Fig. 2.

$$
\mathrm{T} \text { : }
$$

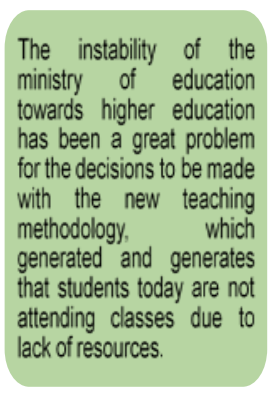

CURRENT SITUATION

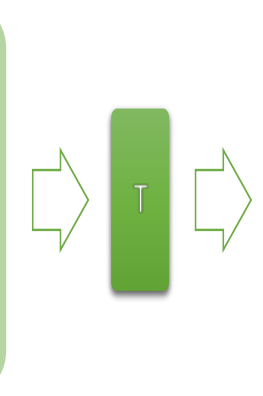

Fig. 2. Basic Definition of Students.

\section{D: Government, Teachers, University.}

W: To establish good learning among all students, the teaching methodology should be better evaluated, as well as the necessary resources that should be implemented in each higher education center.

\section{E: Ministry of Education, Government.}

- W2. TEACHER: An individual who teaches an art or a science, who carries out actions related to teaching at a professional level, since his work in transmitting knowledge and techniques, which are achieved by promoting student learning [22].

\section{C: Student, Teacher, University}

\section{A: Ministry of Education, Sunedu}

T: In the transformation, two different visions can be observed, such as the current and future situation of the teacher, as seen in Fig. 3.

$$
\mathrm{T} \text { : }
$$

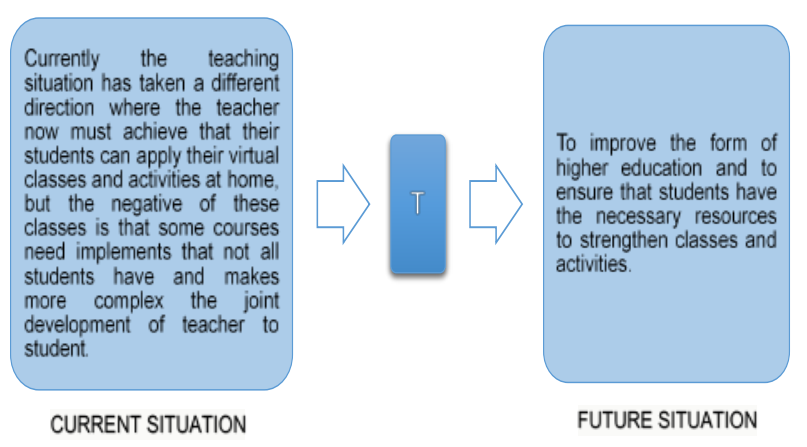

\section{D: Government, SUNEDU, University}

W: Better use should be made of all the possibilities so that the objectives associated with the professional preparation of the student can be met and that training in work skills can be provided for positive integration into the knowledge society and lifelong learning.

\section{E: Ministry of Education, Government}

- W3. UNIVERSITY: A university is an institution of higher education, which is divided into faculties according to the specialties of study that it can offer. The term also applies to the building intended for higher education, that is, an institution organized for the mutual benefit and legal protection of this group [23].

\section{C: Student, Teacher, University}

\section{A: Government, Ministry of Education, Sunedu}

$\mathrm{T}$ : In the transformation, two different visions can be observed, such as the current and future situation of the university, as seen in Fig. 4.

T:

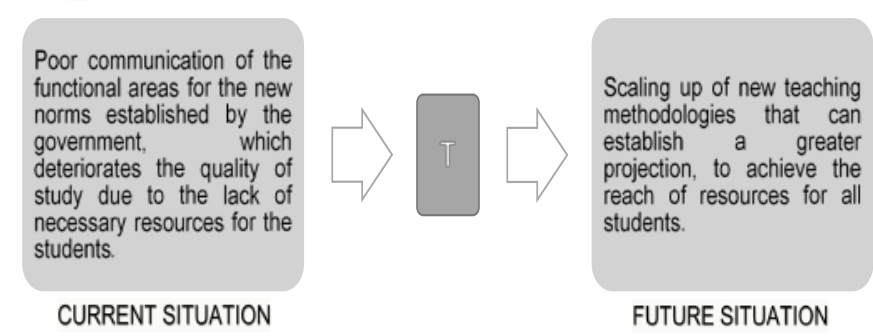

Fig. 4. Basic Definition of University.

D: Government, Ministry of Education, Sunedu, University

W: The problem has taken an exponential turn very quickly which has generated that communication in the academic environment has become difficult to manage and the delimitation of the resources of each student for the production of learning has not been handled correctly so there should be a reinforcement in the selection of regulations according to study methodologies.

\section{E: Government, Ministry of Education, Sunedu}

- W4. MINISTRY OF EDUCATION: The MINEDU is a main body that governs national education policies, which aim to generate opportunities as well as quality to all students to achieve greater development and national competitiveness and teachers strengthen their ability to exercise professionally [24].

\section{C: Student, Teacher, University}

\section{A: Government, Ministry of Education, SUNEDU}

$\mathrm{T}$ : In the transformation, two different visions can be observed, such as the current and future situation of Ministry of Education, as seen in Fig. 5.

Fig. 3. Basic Definition of Teacher. 
$\mathrm{T}:$

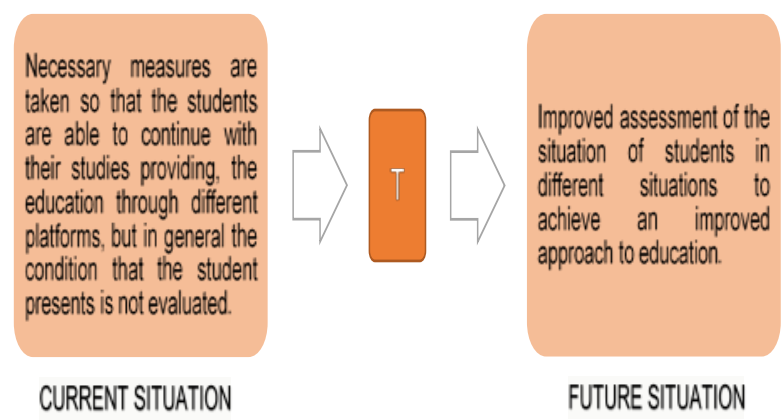

Fig. 5. Basic Definition of Ministry of Education.

\section{D: Government, Sunedu, Ministry of Education}

W: To be able to evaluate the different situations that students in general can present is very difficult, since in our country there is a large percentage of students who do not have the resources or economic means necessary to continue with an adequate education.

\section{E: Government, Sunedu}

- W5. SUNEDU: SUNEDU is responsible for providing licensing to achieve a good service in university higher education, being thus the organization to evaluate the basic conditions of quality as well as to control public resources and correctly administer the national records of degrees and titles [25].

\section{C: Student, Teacher, University}

\section{A: Government, Ministry of Education, SUNEDU}

T: In the transformation, two different visions can be observed, such as the current and future situation of the SUNEDU, as seen in Fig. 6.

T:

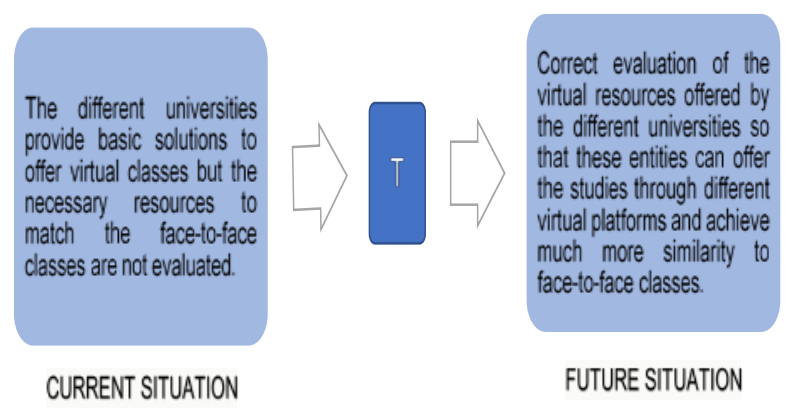

Fig. 6. Basic Definition of SUNEDU.

\section{D: Government, Sunedu, Ministry of Education}

W: The different universities evaluate the best way to offer their virtual classes, but many of them do not manage to facilitate or resemble certain activities as they would be in a face-to-face way.

\section{E: Government, Ministry of Education}

- W6. VIRTUAL PLATFORM: It is known as a system, which can be considered in a technological environment, this achieves the execution of different applications, making the user access through the internet, that is to say that to be able to use it it will not be necessary to be in a specific place, since the only thing that we would need for its due use would be the safe connection to the web. These virtual platforms are generally used for everything related to distance education, because there is a tendency to register the learning in the classroom [26].

\section{C: Student, Teacher, University}

\section{A: Ministry of Education, SUNEDU}

T: In the transformation, two different visions can be observed, such as the current and future situation of the Virtual Platform, as seen in Fig. 7.

$\mathrm{T}:$

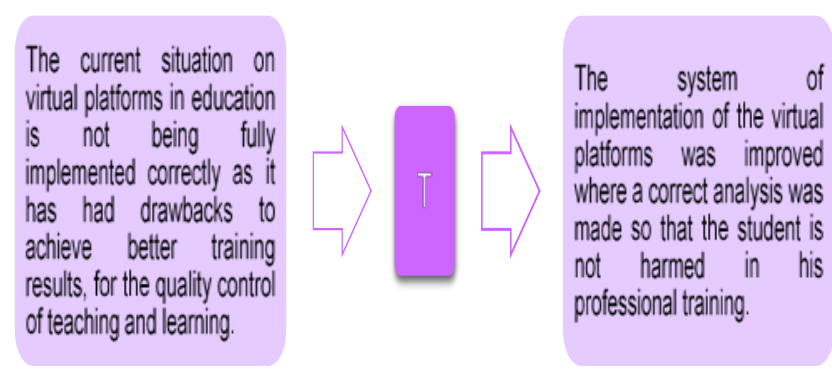

CURRENT SITUATION

\section{FUTURE SITUATION}

Fig. 7. Basic Definition of Virtual Platform.

\section{D: University, SUNEDU}

W: To establish a good use of the virtual platforms between teacher and student it would be necessary to have an evaluation system where the students can count on the necessary resources and so they can have a stable professional education to their working life.

\section{E: Ministry of Education, Government, SUNEDU}

- W7. PARENTS: These are individuals or groups of people who are considered a minimum social unit, consisting of a mother and a father, who promote behavior through education in accordance with moral and social values, thus forming the child's educational process [27].

\section{C: Student, Parent, University}

\section{A: Ministry of Education, Sunedu}

T: In the transformation, two different visions can be observed, such as the current and future situation of the Parents, as seen in Fig. 8. 
$\mathrm{T}:$

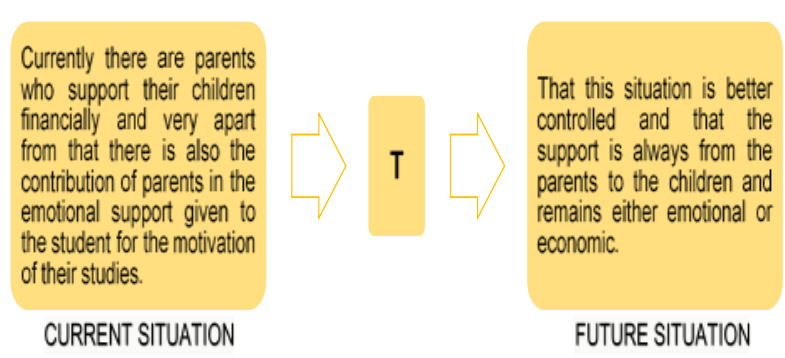

Fig. 8. Basic Definition of Parents.

\section{D: Government, Students, University}

W: This situation has harmed the student in such a way that he or she cannot pay the resources of the university since many of them have the financial support of their parents and apart from the emotional support that they give them and the student's performance improves because of the situation many have been affected considerably.

\section{E: Ministry of Education, Government}

- W8. Virtual classroom: It is known as a digital environment with the possibility of achieving a good development of learning processes. Therefore, information and communication technologies (ICT) allow the student to quickly access the uploaded material and in turn interact with the teacher or other students. [28].

\section{C: Student, Teacher, University}

\section{A: Ministry of Education, SUNEDU}

T: In the transformation, two different visions can be observed, such as the current and future situation of the Virtual classroom, as seen in Fig. 9.

$\mathrm{T}$ :

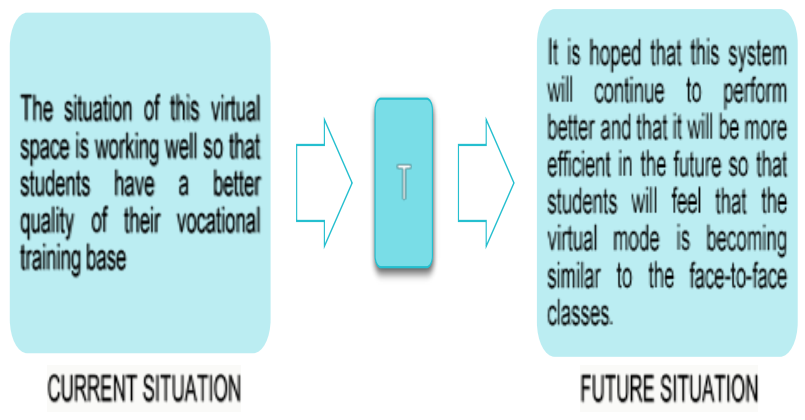

Fig. 9. Basic Definition of Virtual Classroom.

\section{D: SUNEDU, University}

W: It offers us as students facilities such as a more centralized site where we can access the introduction and objectives of learning, also with this modality you can have interaction with colleagues and with the same teachers who can absolve our doubts.

\section{E: Ministry of Education, Government, SUNEDU}

\section{Conceptual Models}

After analyzing the CATDWE, which has an input and output formed in the transformation, for this reason a conceptual model was carried out for each of those involved, which are made up of activities that start with an action verb, thus having a total of 33 activities, with which after an analysis 9 confirmed activities were achieved.

\section{- List of Confirmed Activities}

1) To achieve better development by classifying students who have resources and those who do not in order to achieve better education.

2) To implement methodologies to improve the effectiveness of student teaching by achieving active participation and progress in the practical environment.

3) Provide public recognition and incentives to entities, which establish alliances for the benefit of the student by providing them with scholarships and technological resources.

4) Provide guidance to students and teachers of the different virtual platforms that can be implemented for virtual classes.

5) Determine the mastery of the content presented by the teacher for students in individual and group work according to the resources used in class

6) Improve the use of study tools so that the student has his knowledge reinforced with the implementation of forums and videos to support the classes taught.

7) To carry out surveys and evaluations to the students in order to know in a fast and efficient way with the help of computer tools, obtaining results about their current situation.

8) Carry out a support plan with the help of parents to evaluate and encourage the academic performance of students by visiting the facilities.

9) Monitoring Activities.

\section{E. Primary Task Model Confirmed}

BASIC DEFINITION: A concept that has been developed since the 1980s, this term is attributed to ROXANNE HILTZ who defines it as "the use of computermediated communications to create an electronic environment similar to the forms of communication that normally occur in the conventional classroom". [29].

\section{CATDWE ANALYSIS:}

\section{C: Students, Teachers, University}

A: Ministry of Education, Sunedu

T: In the transformation, two different visions can be observed, such as the current and future situation of the primary task model confirmed, as seen in Fig. 10. 


\section{$\mathrm{T}:$}

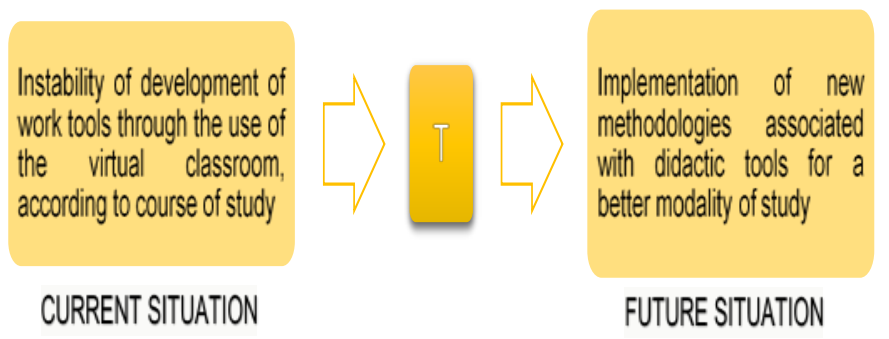

Fig. 10. Primary Task Model Confirmed.

\section{D: Government, Teachers University}

$\mathbf{W}$ : The use of the virtual classroom speeds up the progress of teaching, but more work tools must be implemented to improve this modality of study.

\section{E: Ministry of Education, Government}

In Fig. 11 shows the conceptual model of confirmed and validated tasks, which are related between the control of activities, fearing the situation of the present as input and the future situation as output.

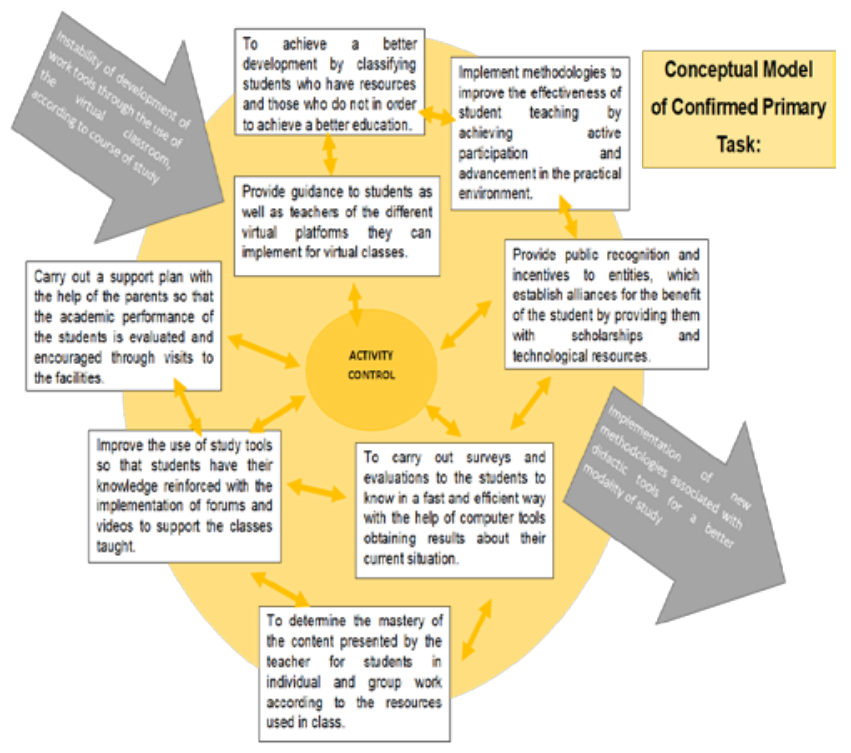

Fig. 11. Conceptual Model of Confirmed Primary Task.

\section{F. Confirmed and Validated Primary Task Model}

BASIC DEFINITION: It is a platform that gives the users the necessary tools to learn, it is a very efficient way to obtain information, and it supports the students with the materials that the teachers use [30].

\section{CATDWE ANALYSIS:}

\section{C: Students, teachers, universities}

\section{A: Ministry of Education, Sunedu}

T: In the transformation, two different visions can be observed, such as the current and future situation of the confirmed and validated task model, as seen in Fig. 12.

$$
\mathrm{T}:
$$

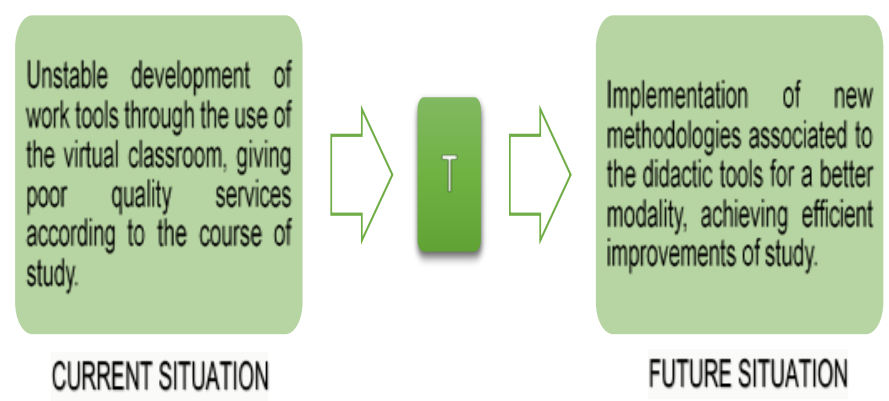

Fig. 12. Confirmed and Validated Primary Task Model Confirmed.

\section{D: Ministry of Education}

W: This provides information to the different students, in addition to the face-to-face class and because in this one can add books, videos as a reference to complete the information explained previously, the knowledge obtained can also be evaluated.

\section{E: Ministry of Education, Government.}

In Fig. 13 shows the conceptual model of confirmed and validated tasks, which are related between the control of activities, fearing the situation of the present as input and the future situation as output.

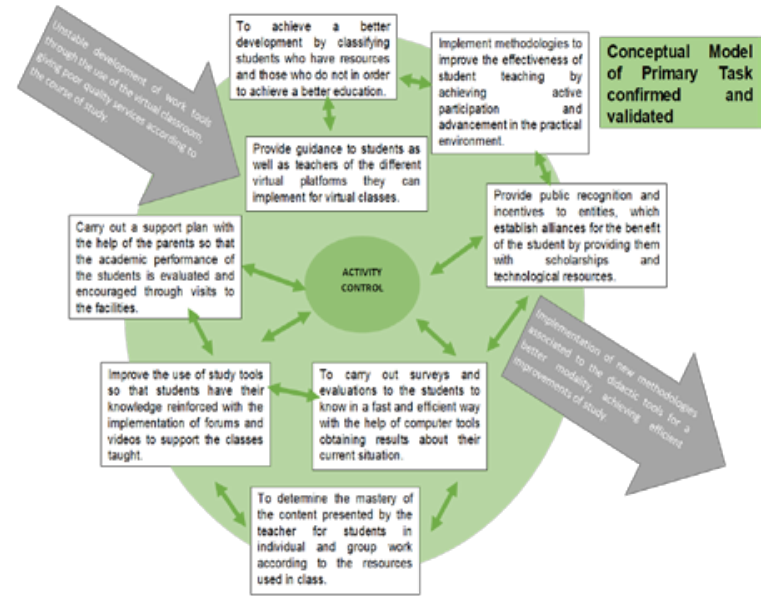

Fig. 13. Confirmed and Validated Primary Task Conceptual Model.

\section{G. Categories of Information}

In this section we analyze the activities that we have confirmed and validated in which different activities were assigned within the inputs as outputs, as can be seen in Table I. 
TABLE I. (A) CATEGORIES OF INFORMATION

\begin{tabular}{|c|c|c|c|c|}
\hline Activity & $\begin{array}{l}\text { Achieve better development by } \\
\text { classifying students who have } \\
\text { resources and those who do not } \\
\text { to achieve better teaching. }\end{array}$ & $\begin{array}{l}\text { Implement methodologies to } \\
\text { improve the effectiveness of } \\
\text { student teaching, achieving active } \\
\text { participation and advancement in } \\
\text { the practical environment. }\end{array}$ & $\begin{array}{l}\text { Provide public recognition and } \\
\text { incentives to entities that } \\
\text { establish alliances for the benefit } \\
\text { of the student, provide them with } \\
\text { scholarships and technological } \\
\text { resources. }\end{array}$ & $\begin{array}{l}\text { Provide guidance to students } \\
\text { and teachers of the different } \\
\text { virtual platforms that they can } \\
\text { implement for virtual classes. }\end{array}$ \\
\hline \multirow{2}{*}{ INPUT } & $\begin{array}{l}\text { Conduct surveys of the tools that } \\
\text { will be used. }\end{array}$ & Implement study models. & $\begin{array}{l}\text { Establish alliances with } \\
\text { academic value. }\end{array}$ & \multirow{2}{*}{$\begin{array}{l}\text { Carry out an orientation } \\
\text { schedule. }\end{array}$} \\
\hline & Make a report of the notes. & $\begin{array}{l}\text { Implement much more student } \\
\text { participation }\end{array}$ & $\begin{array}{l}\text { Establish the correct use of these } \\
\text { platforms }\end{array}$ & \\
\hline \multirow{2}{*}{ OUTPUT } & Evaluate survey & $\begin{array}{l}\text { Evaluate students and review } \\
\text { improvements }\end{array}$ & $\begin{array}{l}\text { Generate academic proposals for } \\
\text { students. }\end{array}$ & List of participants. \\
\hline & Evaluate notes & Answer the students' doubts. & $\begin{array}{l}\text { Winning awards regarding your } \\
\text { high competition. }\end{array}$ & Topics to play. \\
\hline
\end{tabular}

(B) CATEGORIES OF INFORMATION

\begin{tabular}{|c|c|c|c|c|c|}
\hline Activity & $\begin{array}{l}\text { Determine the mastery of } \\
\text { the content that the } \\
\text { teacher presents for the } \\
\text { students in individual and } \\
\text { group work according to } \\
\text { the resources used in } \\
\text { class. }\end{array}$ & $\begin{array}{l}\text { Improve the use of study } \\
\text { tools so that the student } \\
\text { has their knowledge } \\
\text { reinforced with the } \\
\text { implementation of } \\
\text { forums and videos to } \\
\text { support the classes } \\
\text { taught. }\end{array}$ & $\begin{array}{l}\text { Carry out surveys and } \\
\text { evaluations to the students } \\
\text { to know quickly and } \\
\text { efficiently with the help of } \\
\text { computer tools achieving } \\
\text { results on their current } \\
\text { situation. }\end{array}$ & $\begin{array}{l}\text { Make a support plan with } \\
\text { the help of parents so that } \\
\text { the academic performance } \\
\text { of students is evaluated and } \\
\text { encouraged by making } \\
\text { visits to the facilities. }\end{array}$ & Control Activities \\
\hline \multirow{3}{*}{ INPUT } & \multirow{3}{*}{$\begin{array}{l}\text { Survey students about } \\
\text { classes. }\end{array}$} & \multirow{3}{*}{$\begin{array}{l}\text { Survey on programs less } \\
\text { used by students. } \\
\text { Make support videos of } \\
\text { the classes. }\end{array}$} & \multirow{3}{*}{$\begin{array}{l}\text { Carry out some surveys for } \\
\text { the students. }\end{array}$} & \multirow{3}{*}{ Invitation to parents. } & Coordination report \\
\hline & & & & & Work plans. \\
\hline & & & & & $\begin{array}{l}\text { Schedules for } \\
\text { activities. }\end{array}$ \\
\hline \multirow{2}{*}{ OUTPUT } & \multirow{2}{*}{$\begin{array}{l}\text { Evaluate the results } \\
\text { obtained for possible } \\
\text { improvements. }\end{array}$} & $\begin{array}{l}\text { Survey on programs less } \\
\text { used by students. }\end{array}$ & \multirow{2}{*}{$\begin{array}{l}\text { Quickly obtain and } \\
\text { evaluate results. }\end{array}$} & \multirow{2}{*}{$\begin{array}{l}\text { Encourage improved } \\
\text { student development. }\end{array}$} & Report progress. \\
\hline & & $\begin{array}{l}\text { Make support videos of } \\
\text { the classes. }\end{array}$ & & & Activity control report. \\
\hline
\end{tabular}

\section{REsults}

\section{A. Malta Cross}

The Maltese cross is mostly used to be able to analyze the different cardinal points that the problem presents, making combinations between them and thus achieve a good proposal for improvement, as seen in Table II.

\section{B. Analysis Regarding the Malt Cross}

- NORTH WEST VS. NORTH EAST: Universities need quality education that can adapt to situations such as when students have to have materials for their studies, as well as establishing awards to encourage their development and help with different methodologies that help even in the platforms that are being used.

- SOUTH WEST VS. SOUTH EAST: Different systems should be implemented to help control students. In addition, materials and information should be available and assessments should be established to help monitor student progress.

- NORTH EAST VS SOUTH EAST: To monitor the progress of the students it will be necessary to implement different methodologies that help with their progress, they will also have to be evaluated and use the different tools they have.

- NORTH WEST VS SOUTH WEST: To keep us informed about what students need and have, it is necessary to establish surveys in addition to promoting student progress.

- NORTH WEST VS SOUTH EAST: Taking into account the willingness of those involved to complete the various surveys that will be sent to you, so that you can help the collective progress and keep track.

- NORTH EAST VS SOUTH WEST: They want to implement better education and support in the different services they need. 
TABLE II. MALTA CROSS

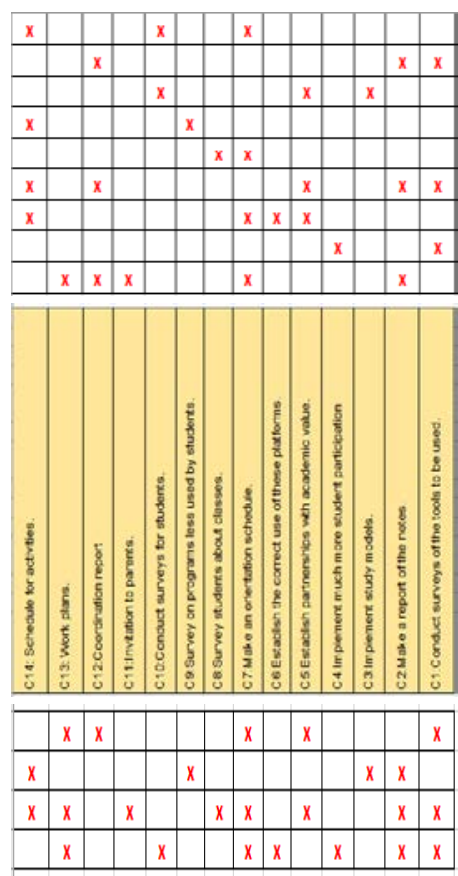

\section{CONCLUSIONS}

With this research we can conclude that the different universities must first carefully analyze all the factors and situations presented by those involved in virtual education, so that they can have better control of activities such as assessment, tasks, forum, correct use platform moddle, and the zoom videoconferences that will be carried out, implementing different methodological systems in the training of teachers, since the central focus must be taken into account for the correct virtual education, advice to teachers and students, to teach them the proper use and implementation of the different tools that can be established in your classes and you can give a good evaluation with the use of these tools. In addition, the Ministry of Education must propose adequate policies to socialize the use of the Internet to the vast majority, that is, to shorten the digital divide and thus be able to obtain a virtual education, taking as a clear example European countries, which before taking any decision regarding education, they always take as central beneficiaries the students, achieving a collective improvement and new innovations within their education, since they take due time for the correct implementation and evaluation of the necessary requirements so that in a university It can include virtual study and there are no differences with classroom classes.

\section{REFERENCES}

[1] S. Urbina and J. Salinas, "Campus virtuales: una perspectiva evolutiva y tendencias", Revista de Educación a Distancia, vol. 42, pp. 6-21, 2014.

[2] C. Sotomayor-Beltran and L. Andrade-Arenas, "A spatial assessment on internet access in Peru between 2007 and 2016 and its implications in education and innovation," 2019 IEEE 1st Sustainable Cities Latin America Conference (SCLA), Arequipa, Peru, 2019, pp. 1-4, doi: 10.1109/SCLA.2019.8905570.

[3] P. Humanante Ramos, F. García Peñalvo and M. Conde González, "Entornos Personales de Aprendizaje y Aulas Virtuales: una Experiencia con Estudiantes Universitarios", IEEE. p. 211, 2013.

\begin{tabular}{|c|c|c|c|c|c|c|c|c|c|c|c|}
\hline$x$ & & & $\mathrm{x}$ & & & & & $x$ & $\mathrm{x}$ & & \\
\hline & & & & & & $x$ & $x$ & $x$ & & $x$ & \\
\hline & $x^{x}$ & & x & $x$ & & & & . & & & \\
\hline & & & & & & $x$ & & $x$ & $x$ & & \\
\hline & $x$ & $x$ & & $x$ & & & & & & & \\
\hline \begin{tabular}{|l}
$x$ \\
\end{tabular} & & $x$ & & & & & $x$ & & & & \\
\hline$x$ & $x$ & & & & & & & & & & \\
\hline & & & $x$ & & & & & & $x$ & & $x$ \\
\hline & & & & & & $x$ & & & & & \\
\hline
\end{tabular}

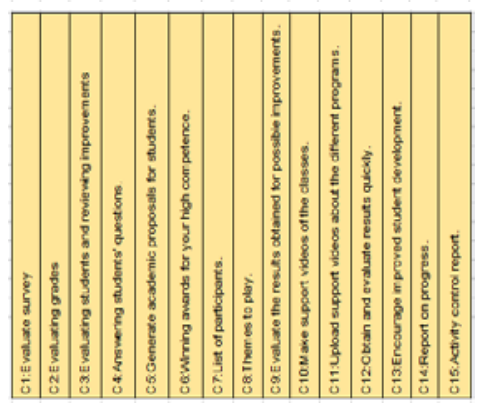

PPI

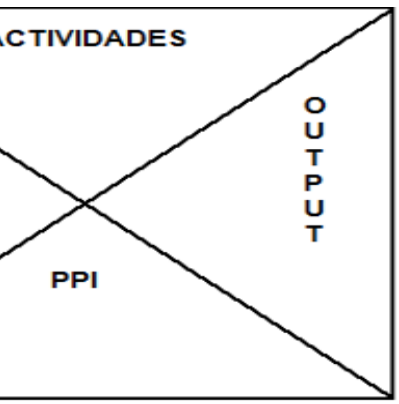

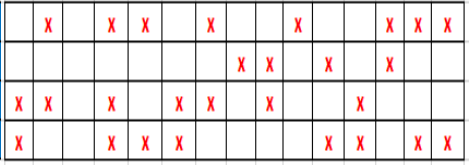

[4] Universidad Santo Tomás, "Proyecto Educativo Institucional", Bogotá: USTA, 2004.

[5] C. Villanueva Ipanaqué, "Medición Del Impacto De Las Tic En La Enseñanza-Aprendizaje De La Profesión Contable.", Revista de la Facultad de Ciencias Contables, 2016.

[6] J. Cabañas Valdiviezo and Y. Ojeda Fernández, "Aulas virtuales como herramienta de apoyo en la educación de la Universidad Nacional Mayor de San Marcos", Tesis de pregrado, Universidad Nacional Mayor de San Marcos, 2013.

[7] R. Bello Díaz, "Educación Virtual: Aulas sin Paredes.", Educar, 2005. [Online]. Available: http://www.educar.org/articulos/educacionvirtual.asp.

[8] V. García Balaguera, "El Uso De Las Aulas Virtuales Como Recurso Didáctico Y Pedagógico En De La División De Ingenierías De La Universidad Santo Tomás", En Proyecto Educativo Institucional, Bogotá: USTA, 2004.

[9] M. Delgado Fernández and A. Solano González, "Estrategias Didácticas Creativas En Entornos Virtuales Para El Aprendizaje.", Actualidades Investigativas en Educación, 2009.

[10] C. School, "CATWOE: la lista de chequeo que permite entender cualquier sistema", Cerem.pe, 2018. [Online]. Available: https://www.cerem.pe/ blog/catwoe-para-tus-problemas. [Accessed: 22- May- 2020].

[11] M. Área Moreira, M. San Nicolás Santos And E. Fariña Vargas, Buenas Prácticas De Aulas Virtuales En La Docencia Universitaria Semipresencial. 2010.

[12] B. Gregori, E And B. Garganté, A, "El uso educativo de las aulas virtuales emergentes en la educación superior", Dialnetplus. 2005.

[13] Flores Rivera, "El uso de herramientas en línea para fortalecer el aprendizaje autónomo de los estudiantes de la escuela de administración de empresas de la Pontificia Universidad Católica del Ecuador sede Ambato,", Tesis, Universidad Nacional de Loja, Educación, El Arte Y La Comunicación, 2015.

[14] "Estudiar con la ayuda de las nuevas tecnologías - educaweb.com", Educaweb.com, 1998. [Online]. Available: https://www.educaweb.com/ contenidos/educativos/tecnicas-estudio/estudiar-ayuda-nuevastecnologias/.

[15] Cabero And M. Gisbert, "La formación en Internet. Guía para el diseño de materiales didácticos", MAD, Sevilla, 2005.

[16] Adell And A. Sales, "El profesor online: elementos para la definición de un nuevo rol docente.", Comunicación al III Congreso EDUTEC. Málaga, 1999. 
[17] F. Díaz Barriga And G. Hernández Rojas, "Estrategias Docentes para un Aprendizaje Significativo: Una interpretación constructivista.", México, 1999.

[18] B. Khan, "Web-Based Training.", New Jersey: Englewood Cliffs., 2001.

[19] L. Morán, "Blended-learning. Desafío y oportunidad para la educación actual.", Edutec, Revista Electrónica de Tecnología Educativa, no. 39, 2012.

[20] S. O’Neill, K and J. O’Donoghue, "Implementing e-learning Programmes for Higher Education", A Review of the Literature. Journal of Information Technology Education, vol. 3, pp. 313-323, 2004.

[21] M. Rodríguez Malmierca, El estado del e-learning en Galicia. Análisis en la Universidad y empresa. 2006.

[22] R. Adrián, "¿Qué es Estudiante? Su Definición y Significado [2020]", Concepto de - Definición de, 2020. [Online]. Available: https://conceptodefinicion.de/estudiante/.

[23] M. Pérez, "¿Qué es Universidad?» Su Definición y Significado", Concepto de - Definición de, 2020. [Online]. Available: https://conceptodefinicion.de/universidad/.
[24] J. Pérez Porto, "Definición de profesor — Definicion.de", Definicion.de, 2019. [Online]. Available: https://definicion.de/profesor/.

[25] "Significado de Familia", Significados, 2019. [Online]. Available: https://www.significados.com/familia/.

[26] "Funciones", Minedu.gob.pe, 2020. [Online]. Available: http://www.minedu.gob.pe/p/ministerio-funciones.php.

[27] "Historia y funciones", SUNEDU, 2016. [Online]. Available: https://www.sunedu.gob.pe/historia.

[28] J. Porto and A. Gardey, "Definición de plataforma virtual", Definicion.de, 2013. [Online]. Available: https://definicion.de/plataforma-virtual/.

[29] J. Pérez Porto and M. Merino, "Definición de aula virtual", Definicion.de, 2016. [Online]. Available: https://definicion.de/aula-virtual/.

[30] V. Cabañas and E. Julia, "Aulas virtuales como herramienta de apoyo en la educación de la Universidad Nacional Mayor De San Marcos. Sistema de Bibliotecas", Tesis, Universidad Nacional Mayor De San Marcos, 2002. 